\title{
Rational Emotive Behavior Therapy to Improve Students Confidence
}

\author{
$1^{\text {st }}$ Alivermana Wiguna \\ Guidance and Counseling Department \\ STKIP Muhammadiyah Sampit, \\ Indonesia \\ alivermanawiguna@gmail.com
}

\author{
$2^{\text {nd }}$ Agus Heriyanto \\ Guidance and Counseling Department \\ STKIP Muhammadiyah Sampit, \\ Indonesia
}

\author{
$3^{\text {rd }}$ Zainatul Humairo \\ Guidance and Counseling Department \\ STKIP Muhammadiyah Sampit, \\ Indonesia
}

\begin{abstract}
Most students have low self-confidence, such as afraid of arguing, asking the question and even speak in front of the class. This study aimed to increase student selfconfidence with rational emotive behavior therapy individual counseling approach cognitive technique trough low self-confidence student. This study uses qualitative methods with a case study approach. The number of students who were the subject of this study was only one person. The technique of collecting data used source triangulation. The results of data analysis in this study indicate that rational emotive behavior therapy individual counseling approach cognitive technique on low self-esteem on a student of class $X$ at SMKN 2 Sampit showed that the subject experienced better changed to the problems of low self-confidence.
\end{abstract}

Keywords-Emotive Behavior, Therapy, Improve, Student Confidence

\section{INTRODUCTION}

According to LAW No. 20/2003 in Amialia [1] on the national education system, education is a planned conscious effort to create a learning atmosphere and learning process so that learners actively develop their potential to have Spiritual strength, self-control, personality, intelligence, noble morality, and the skills he needs, society, nation, and country. So, the purpose of education is the opportunity to develop self-control in individuals. However, not all individuals experience good self-control. From the results of the previous study conducted in SMK Negeri 4 Sampit showed the case of one of the students failed in developing his confidence. According to the explanation given by the subject, that he felt unconfident in his opinion, asked and performed in front of the class. This is because the subject of thinking will be laughed at by his friends, and is afraid to blame when there is a mistake in arguing or answering.

Failure to develop confidence will greatly affect someone in socializing or interacting. This is evidenced by the case of students in MTs Nurul Yaqin in the district of Ketapang, Kotawaringin Timur. The student admits that he has low confidence. He was afraid to face mathematical lessons, and he felt no skills in the subject matter. As a result of such low confidence students rarely attended school and eventually quit school. From the exposure, it can be concluded that by letting the low belief and not change it will result in negative impact and selfharm.

Unlike the person who has a good confident development. It can be proved that with good confidence will bring positive. It can be seen from the realized fact, that with confidence will give birth to something positive.
Parara Wendy Indarjo of Sampit residents graduate SMAN 1 Sampit, with poor family conditions and both parents are sickly. Parara with daily life only eats rice with soy sauce is not suspected can pass in IPB (Agricultural Institute of Bogor) and graduated with a GPA of 4.00. This is because Parara believes in his abilities that he can certainly succeed in the future. With the confidence and motivation that Parara has brought an unexpected achievement, namely with a graduate of IPB with IPK, with the value of 4.00. From this event, it can be concluded that with the high confidence will achieve positive and satisfactory results (M. Kalteng. Prokal. $\mathrm{CO} / \mathrm{read} / 20713$ ).

Likewise experienced by the subject, that he included students who failed in developing good self-confidence. So, the problem formulation of the background is how is the increase in student confidence by using Rational Emotive Behavior Therapy with cognitive techniques? This research can increase knowledge of education and counseling. Specifically related Rational Emotive Behavior Therapy with cognitive techniques in students ' low confidence in enhancing the subject's self-confidence.

Nelson [2] states the approach of Rational Emotive Behavior Therapy (REBT) looks at that all human beings have three fundamental goals (fundamental objectives) i.e., to stay alive, to be relatively free from pain, and to be quite satisfied. Komalasari [3] stated that the Rational Emotive Behavior Therapy (REBT) approach is a cognitive approach that emphasizes the interconnectedness of feelings, behavior, and thoughts. According to Ellis in Nelson [2], REBT emphasizes real change, he also teaches Conley to fight irrational ideas and self-defeating behaviors (the idea that sometimes people deliberately do things that will make them fail or involved problems.

Komalasari [3] States the main purpose of REBT is to help individuals realize that they can live a more rational and productive life. The goal of REBT is to help individuals achieve value for life and to enjoy life. The objectives are divided into several sub-objectives namely, having a personal interest, have a social interest, have selfbriefing, tolerance, flexible, have acceptance, can accept uncertainty, can accept themselves, can take risks, Have realistic expectations, have personal responsibilities. Setiawan [4] (2018:168) stated the general purpose of REBT is to assist people in minimizing emotional distractions, self-decline self-behavior, and be selfactualized (self-actualization) so that they can live a happy life. According to Pujosuwarno the objective of rational 
emotive Counseling is: (1) correcting and changing attitudes, perception, way of thinking, belief as well as irrational views of Counseling are becoming rational so that the Counseling can develop themselves, increase self The Actualizational is as optimal as possible through positive cognitive and affective behavior. (2) Eliminate self-destructive emotional disorders such as hate, pain, guilt, guilt, anxiety, profusion, and resentment.

Rational Emotive Behavior Therapy (REBT) has several types of techniques in it. There are cognitive techniques, imagery/imagination techniques, and behavioral techniques. The technique of being used in this research is a cognitive technique, which is a technique used to change the way of thinking Counseling Dewa Ketut in Lubis [5] explains that there are four stages in cognitive Engineering: (1) The teaching stage, in the REBT counsellor takes a more active role than a student. This stage provides the counsellor to speak and show something to the contemplation especially showing how the unlogic thinks it directly poses an emotional disorder. (2) The persuasive stage is to convince the counseling to change his view because of the view that concocted is not true. Counsellors also try to convince the various arguments to show what the counseling considers is untrue. (3) The confrontation stage is that the counsellor altered the irrational of the counseling and brought the counseling toward more logical thinking (4) stage of the assignment, whereby the counsellor gave the task to the counseling to try to perform a specific action in a Real situation. For example, assigning counseling to community members if they feel they are being decompressed from the association or giving a book to correct the wrong way of thinking.

Komalasari [3] states the steps or stages of counseling with the REBT approach are: (1) cooperate with counseling. (2) Conduct assessment against problems, people and situations. (3) Preparing the counseling for therapy. (4) Implementing the Handling program. (5) Evaluating progress. (6) Preparing the counseling to end counseling. Counseling is conducted three cycles. In the first cycle, the author conducts counseling aims to know the problems that are experienced counseling. In the second cycle, the author began using the REBT approach with cognitive engineering. In the third cycle, the author asks if there is any change or not after conducting counseling.

According to Supriyo [6], confidence is a deep feeling in one's inner self, even he can do something for himself, his family, the peoples, the people, and his religion. Motivate counseling to be optimistic, creative and dynamic positive. While low confidence according to Maslow in the Enterprise [7] The sense of lack of confidence sometimes appears suddenly to someone when doing something so that the person is unable to demonstrate or remove the ability Truly optimally. According to the judge in Yessi (2017:5) Less confident is a condition in which individuals have doubts about the belief of self-ability, an example of someone who feels unable is unsure in conveying an opinion in front of people Many. It can be deduced from the explanation above that confidence is low or less confident is a situation where individuals have doubts about the belief of selfability and always think about themselves and the ability to have.

According to the judge in Vandini [8] factors that can affect the belief, there are internal factors i.e. (1) Selfconcept, (2) Self-esteem, (3) physical condition, (4) Life experience. While the external factors are (1) education, (2) work, (3) environment and life experience. According to Supriyo (2008:45-46), someone who has selfconfidence can be seen from the following traits: (1) A feeling of fear or trembling while talking to the crowd. (2) The posturing attitude to failure, looking at a gloomy future. (3) Feelings less loved or less appreciated by the surrounding environment. (4) Less pleased with the success of others, especially peers or generations. (5) Excessive inner sensitive, irritability, swift temper, vengeful. (6) Like to be alone and tend to be egocentric. (7) Be overly cautious when dealing with others so that behavior looks stiff. (8) The movements are somewhat limited as if realizing that he does have many shortcomings. (9) Often refuse when invited to crowded places.

Low confidence can occur through a lengthy process that starts with education in the family. (1) The formation of various weaknesses in different aspects of a person's personality starts from family life and covers various aspects, such as mental, physical, social and economic aspects. (2) A person's negative understanding of himself tends to always think of deficiencies without ever believing that he or she also has an advantage that other people may not have. (3) The social life that is lived with negative attitudes, such as feeling inferiority, self-esteem, escaping responsibilities, isolating themselves from the group, and other negative reactions, which further strengthens the sense of lack of confidence in the Someone.

\section{METHOD}

The place that used to research in SMK Negeri 4 Sampit. The study was conducted from March to May 2019. This type of research is qualitative research with a case study approach. The number of students being the subject of this study amounted to one of the initials of WA. The operational definition is (1) Rational Emotive Behavior Therapy, (2) confidence. Data collection techniques using source triangulation. In the triangulation of the source, there are several instruments used are interviews, observation, Checklist issue models, and documentation.

\section{RESULT}

WA's low self-esteem like fear and shame argues, asks, even forwards to the front of the class. This also affects the social relations of WA, where WA prefers to be alone than to gather with her friends. Before giving the instrument to WA, the author first interviewed with other informants such as his teacher and friend class.

The author performs interviews, observations, and DCM models before counseling to WA. The results 
obtained are: (1) WA always feel nervous, shaky and afraid wrong if forward to the front of the class, argue, even ask. (2) difficult to adapt. (3) Often aloof if there are empty hours or breaks. (4) A lot of silence if in the classroom. (5) doubting his abilities. Next, conduct interviews, observations, and Models Check issue checklist (DCM) after three cycles of counseling. The results that WA gained are changing, namely the diminishing traits of low confidence she has. The author has done three cycles of counseling. The first cycle begins with the REBT approach counseling stage and discusses the problems of low confidence that the subject has experienced. The author asks whether the problem the subject is experiencing is including the traits of low confidence. The goal of first cycle counseling is to know the problems experienced. In the second cycle, the beginning of the discussion equals the first cycle. Furthermore, the authors began using REBT approaches with cognitive engineering. Then the author directs the subject statement regarding his unbelief with the application of REBT counseling using cognitive techniques. This second cycle, a curse to apply the REBT approach. The author directs the subject's mindset to have a choice of actions to take. The author gives the question of whether any action will be channelled in increasing his confidence. Subsequently, the author concluded the second cycle counseling. The third cycle, aiming to know if there is any change in the subject during counseling. The individual counseling of this cycle of 3 , WA says that there has been a change in her with her steps or actions she has chosen. After conducting individual counseling for three WA cycles have changed. WA began to dare to advance to the front of the class, began to dare to ask or argue, even WA mingled with his other friends. Besides, WA no longer thinks negative about her and her abilities. After counseling, the traits of low-confidence WA have a reduction. WA was able to fight her shyness and fear wrong when she progressed to the front of the class, argued or asked. Then, WA already mingles with other friends, in other words, WA no longer aloof, and when in the classroom WA more confident.

The results of the Checklist issue Model, observations and interviews can be seen below:

A. Checklist issue model Results

\begin{tabular}{|c|c|c|c|}
\hline No. & Aspects of the problem & $\begin{array}{l}\text { Before Counseling } \\
(\%)\end{array}$ & $\begin{array}{l}\text { After Counseling } \\
(\%)\end{array}$ \\
\hline 1. & Feelings of fear or trembling while talking to the crowd. & 16,7 & 11,1 \\
\hline 2. & $\begin{array}{l}\text { The attitude of the resignation on failure, looking at the } \\
\text { gloomy future. }\end{array}$ & 11,1 & 11,1 \\
\hline 3. & $\begin{array}{l}\text { Feelings less loved or less appreciated by the surrounding } \\
\text { environment. }\end{array}$ & 11,1 & 22,2 \\
\hline 4. & $\begin{array}{l}\text { Less pleased with the success of others, especially peers } \\
\text { or generations. }\end{array}$ & 0 & 0 \\
\hline & $\begin{array}{l}\text { The inner sensitive is excessive, irritable, fast temper, } \\
\text { vengeful. }\end{array}$ & 11,1 & 11,1 \\
\hline & Like to be alone and tend to be egocentric. & 16,1 & 11,1 \\
\hline & $\begin{array}{l}\text { Be too cautious when dealing with others so that behavior } \\
\text { looks stiff. }\end{array}$ & 11,1 & 22,2 \\
\hline & $\begin{array}{l}\text { The movements are somewhat limited as if realizing that } \\
\text { he does have many shortcomings. }\end{array}$ & 11,1 & 11,1 \\
\hline & Often refuse when invited to crowded places. & 11,1 & 0 \\
\hline
\end{tabular}

From the results of a DCM model that has been given to the subject before the implementation of individual counseling, the author gets the result that feelings of fear and trembling when talking with the crowd and like being isolated and egocentric. From the result of the overall aspect of the item that has been selected by the subject as many as 18 choices, the total percentage of $67 \%$ belongs to the category less once. Then, from the second DCM model given to the subject after individual counseling, from the overall matter of the issue that has been selected by the subject as many as 9 choices, the result is $33 \%$. Thus, the subject undergoes a low confidence reduction in itself as much as $34 \%$ of the initial yield of $67 \%$.
The results of research through observation gained the result that WA does have a factor of low confidence cause. From the aspect observed almost all aspects of the WA almost have it. From observation when before individual counseling WA always show from every activity during school as the expression of the feeling of the night, fear of wrong and the problem that bothers him. The observation results after the implementation of individual counseling showed a change in WA self. From WA activities while in school it looks its change, where WA has dared to mingle with other friends, WA began to dare to express herself, already believes that she has the ability or talent on her. His belief in himself was highly visible through his bravery when he progressed to the front of the class and expressed his opinion.

C. Interview Results

\section{B. Observation results}


From interviews before and after individual counseling that before conducting individual WA counseling has traits of low confidence in him. However, after individual counseling during the three cycles, WA has changed the low confidence that is owned and has seen increased confidence in WA. The interview results can be seen in the table below.

TABLE 2. INTERVIEW RESULTS BEFORE AND AFTER COUNSELING

\begin{tabular}{|c|c|c|c|}
\hline No. & Aspects of the problem & Before Counseling & After Counseling \\
\hline 1. & $\begin{array}{l}\text { Feelings of fear or shaking } \\
\text { while talking to the crowd. }\end{array}$ & $\begin{array}{l}\text { I am often nervous, what else if I } \\
\text { come forward fear wrong when } \\
\text { talking ahead of many people. }\end{array}$ & $\begin{array}{l}\text { Alhamdulillah, now I start to dare to come to the front of } \\
\text { the class and speak in front of the crowd and better than } \\
\text { ever, who at first I doubt will but I keep trying until I dare } \\
\text { to come forward with my desires. }\end{array}$ \\
\hline 2. & $\begin{array}{l}\text { The attitude of the resignation } \\
\text { on failure, looking at the } \\
\text { gloomy future. }\end{array}$ & Yes trying, so as not to this like. & $\begin{array}{l}\text { For that matter, I always try and try, if anything I do not } \\
\text { understand, I ask my friends to ask for explanations, this I } \\
\text { do so that I do not get the same value again (less } \\
\text { satisfactory). }\end{array}$ \\
\hline 3. & $\begin{array}{l}\text { Feelings are less loved or less } \\
\text { appreciated by their } \\
\text { surroundings. }\end{array}$ & $\begin{array}{l}\text { Often (opinions rejected), do not } \\
\text { know also why such. }\end{array}$ & Sometimes rejected accepted my opinion. \\
\hline 4. & $\begin{array}{l}\text { Less pleased with the success } \\
\text { of others. }\end{array}$ & $\begin{array}{l}\text { No, I don't want to think } \\
\text { negatively about friends. }\end{array}$ & No, I don't want to think negatively about friends. \\
\hline & $\begin{array}{l}\text { Inner sensitive overload, } \\
\text { irritability, fast temper, } \\
\text { vengeful. }\end{array}$ & $\begin{array}{l}\text { Ordinary (feel excessive when } \\
\text { friends joke).- }\end{array}$ & No, I'm looking for peace. \\
\hline & $\begin{array}{l}\text { Like to be alone and tend to be } \\
\text { egocentric. }\end{array}$ & Me more often myself. & $\begin{array}{l}\text { Now I can get together or mingle with other friends when } \\
\text { my empty hour is not only with a classmate, but with the } \\
\text { other class children. }\end{array}$ \\
\hline & $\begin{array}{l}\text { Be too cautious when dealing } \\
\text { with others. }\end{array}$ & $\begin{array}{l}\text { I was nervous and ashamed of the } \\
\text { same new known people. }\end{array}$ & $\begin{array}{l}\text { It could be, although sometimes I still feel embarrassed, I } \\
\text { keep trying to fight my embarrassment and eventually, I } \\
\text { can start to talk to other people, what's more with the } \\
\text { newly-made people. }\end{array}$ \\
\hline & $\begin{array}{l}\text { His movements were } \\
\text { somewhat limited as if he } \\
\text { realized that he had many } \\
\text { weaknesses. }\end{array}$ & As long as I understand. & $\begin{array}{l}\text { Always ready, I always work on the task given by the } \\
\text { teacher, but if there is a problem that I do not understand, I } \\
\text { ask a friend and ask for an explanation. If the same does } \\
\text { not understand, as only, at least I completed the task given. }\end{array}$ \\
\hline 9. & $\begin{array}{l}\text { Often resist the call of friends } \\
\text { to crowded places. }\end{array}$ & Friends cool down so I often sleep. & $\begin{array}{l}\text { Yes, now I am not as it used to be, now I am more often } \\
\text { gathered with other friends. }\end{array}$ \\
\hline
\end{tabular}

The results of this study showed no better changes in the subject, originally $66.66 \%$ of the problems encountered by counseling, then paid $33.33 \%$ after counseling using REBT. The results of this study showed conformance with research conducted by Fakihatur Rahma (2014) under the title "Application of Rational emotional counseling behavior to reduce low feelings of class XI students in SMK Maskumambang 2 Gresik". The SMK students experience such low confidence, fear of wrong and fear of being ridiculed by his friends, so that shows less active and tends to be passive when in the classroom. Researchers of this problem use the application of rational behavior counseling behaviors to improve and change attitudes, views, ways of thinking that are not rational become rational. From the research explanation of the problem, obtained in the phase of intervention that has been done and it is obtained shows that there is a change of students and can reduce the feeling of low himself and has become more confident and social interaction with Friends and courage when advancing in front of the class.

The same is the result of the research that the author is doing grade X ATP 2 students at SMK Negeri 4 Sampit. The results gained are increased self-esteem in the subject by using the REBT counseling approach with cognitive engineering.

\section{CONCLUSION}

Individual counseling Rational Emotive Behavior Therapy (REBT) with cognitive techniques on low confidence one of the grade X students in SMKN 2 Sampit has an increase in his confidence and can be said to be quite successful. WA shows changes after individual counseling. WA dared to advance to the front of the class without being appointed, then WA has begun to ask when there is a lesson that is not understood, no longer aloof. WA has changed its mindset, which was originally irrational into rational. But there are still those who have not yet demonstrated a change of feeling less loved or less appreciated by the surrounding environment and too cautious when dealing with others so that his behavior looks stiff.

\section{REFERENCES}

[1] Amialia, Landasan Pendidikan, Depok: Prenada Group, 2017.

[2] Nelson, Teori dan Praktik Konseling dan Terapi, Yogyakarta: Pustaka Pelajar, 2011.

[3] Komalasari, Teori dan Teknik Konseling, Jakarta: Indeks, 2018. 
[4] Setiawan, Pendekatan-pendekatan Konseling (Teori dan Aplikasi), Yogyakarta: Deepublish, 2018.

[5] L. Lubis, Konseling Kelompok, Jakarta: Kencana, 2016.

[6] Supriyo, Studi Kasus Bimbingan dan Konseling, Semarang: CV. Nieuw Setapak, 2008.

[7] D. I. Enterprise, Satu Hari Menuju Lebih Percaya Diri, Jakarta: Gramedia, 2014.
[8] I. Vandini, "Peran Kepercayaan Diri terhadap Prestasi Belajar Matematika Siswa," Formatif, pp. 20162017, 2015. 